\title{
JADWIGA LEWANDOWSKA
}

\section{Pozostałości cegielni w Starym Rypinie}

\section{Remains of a brickyard in Stary Rypin}

Zarys treści. Artykuł prezentuje wyniki badań archeologicznych stanowiska 4 w Starorypinie Prywatnym (gm. Rypin, woj. kujawsko-pomorskie), przeprowadzonych w latach 2014-2017. Miejsce to osadniczo wykorzystywane było w pradziejach i wczesnym średniowieczu, o czym świadczą jamy gospodarcze, natomiast w późnym średniowieczu i okresie nowoży tnym funkcjonowała tu cegielnia. Na stanowisku odsłonięto pozostałości późnośredniowiecznego, dwukomorowego pieca do wypału cegieł z zachowanym całym wsadem. Według typologii średniowiecznych pieców ceglarskich można go zaliczyć do typu I b, posiadającego dwie komory ogniowe (Hennrich 2003). Rezultat datowania luminescencyjnego cegieł wskazuję, że mur, z którego pochodził materiał datujący po raz ostatni poddany został działaniu wysokiej temperatury 705 lat temu, przy minimalnej niepewności tego oszacowania 41 lat. Natomiast datowanie ${ }^{14} \mathrm{C}$ węgla drzewnego pochodzącego z wejścia do komory północnej wskazują na czas $745 \pm 30$ BP. W innym miejscu stanowiska 4 natrafiono na dwa kolejne piece, dużo młodsze - datowane wstępnie na XIX wiek. Stanowi to dowód na tradycję miejsca, zapewne wynikającą z dostępności i jakości surowca.

Slowa kluczowe: ziemia dobrzyńska, średniowiecze, cegielnia, piec do wypału cegieł.

W krajobrazie kulturowym północnej części ziemi dobrzyńskiej znaczącą rolę zarówno we wczesnym, jak i późnym średniowieczu odgrywał zespół osadniczy w Starym Rypinie, dziś położony w miejscowości Starorypin Prywatny (gm. Rypin, woj. kujawsko-pomorskie).

${ }^{1}$ W niniejszym artykule zastosowano określenie Stary Rypin, co jest zasadne zwłaszcza dla dziejów grodu, a następnie lokowanego na tym miejscu miasta w 1. połowie XIV wieku, kiedy występował wyłącznie jeden Rypin. W literaturze znaleźć można także inne określenia; od czasu pojawienia się w źródłach nowego miasta Rypina, w odniesienu do dziejów starego grodu używana jest już nazwa Stary Rypin - wobec wyraźnie zaznaczanego w źródłach Nowego Rypina - lub Starorypin. 


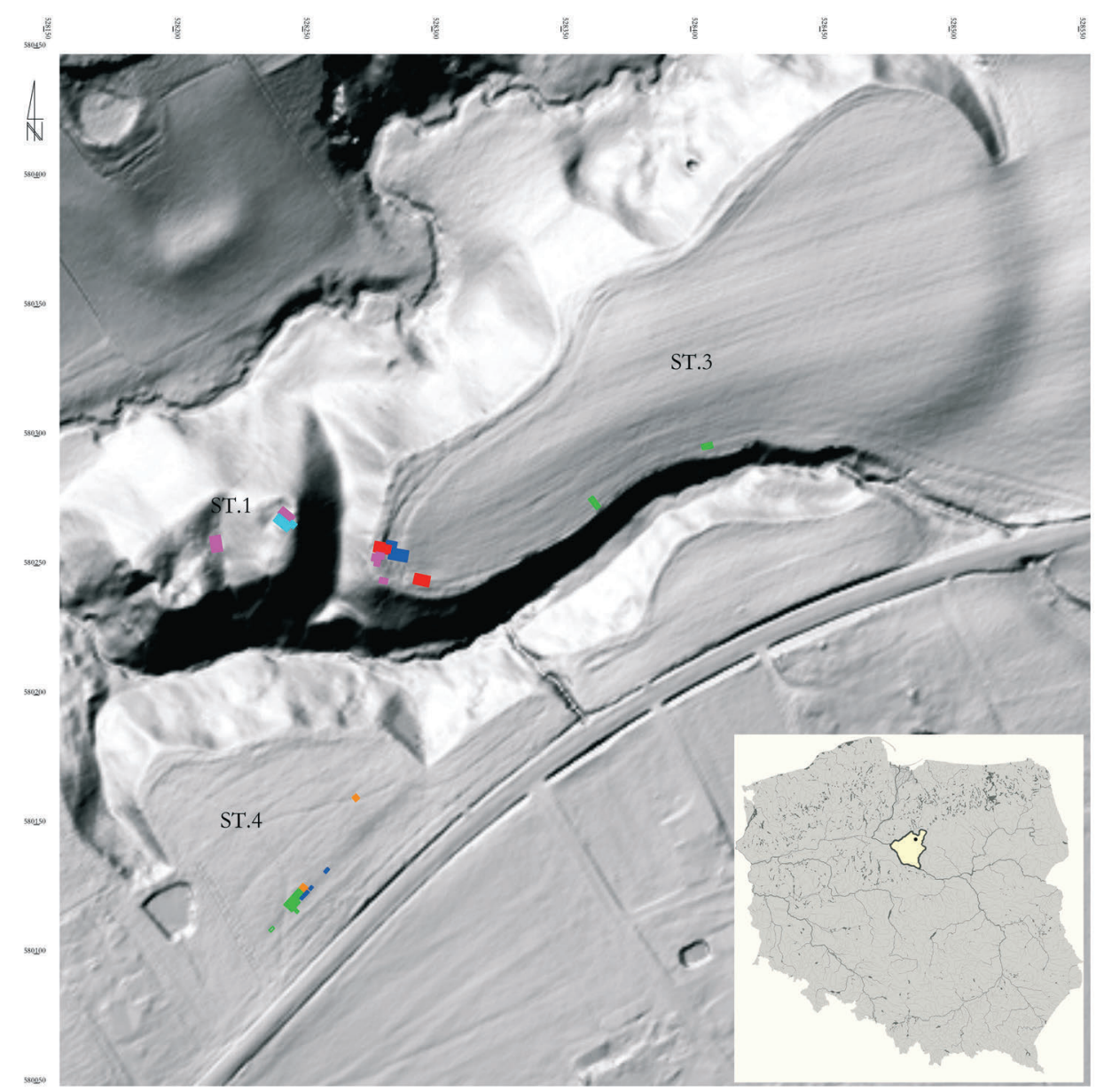

ZESPÓE OSADNICZY W STARORYPINIE - ZBIORCZE ZESTAWIENIE WYKOPÓW ARCHEOLOGICZNYCH

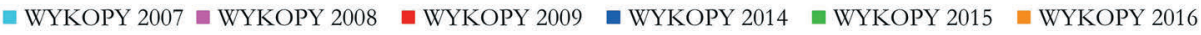

Ryc. 1. Stary Rypin, woj. kujawsko-pomorskie. Lokalizacja wykopów badawczych z lat 2007-2016 (oprac. J. Lewandowska)

Fig. 1. Stary Rypin, Kuyavian-Pomeranian Voivodeship. Location of trenches from 2007-2016 (edited by J. Lewandowska)

W wyniku badań wykopaliskowych i nieinwazyjnych w obrębie tego rozległego kompleksu osadniczego zweryfikowano dotychczas trzy stanowiska archeologiczne (ryc. 1) (Lewandowska 2011, s. 541-552; 2016, s. 125-148). Stanowisko 1 jest pozostałością po obiekcie obronnym, który funkcjonował we wczesnym i późnym średniowieczu jako miejsce centralne. Rozległe stanowisko 3 skrywa relikty osady ludności kultury pomorskiej (Lewandowska, Szymkowicz, w druku), wczesnośredniowiecznej osady podgrodowej, osady późnośredniowiecznej (pierwszego rypińskiego civitas?) oraz cmentarza późnośredniowiecznego. 
Stanowisko 4 zawiera zaś ślady nie tylko o charakterze osadniczym, ale także przemysłowym (por. niżej).

Badania archeologiczne na stanowisku 4, pod kierunkiem autorki tekstu, przeprowadzono dotychczas w różnym zakresie w latach 2014-2017 (ryc. 2)². Na podstawie ich wyników uściślono funkcję tego miejsca, które osadniczo wykorzystywane było we wczesnym średniowieczu, o czym świadczy obecność jam gospodarczych z ułamkami naczyń ceramicznych oraz zwierzęcymi szczątkami kostnymi. W późniejszym czasie natomiast działała tu cegielnia.

Implikacją odkryć dokonanych na stanowisku 4, a zwłaszcza pieca do wypału ceramiki budowlanej o późnośredniowiecznej metryce, jest próba opisu wyrobu cegieł - od przygotowania gliny, po jej wypał, co zostało już zaprezentowane w literaturze przedmiotu (m.in. Wyrobisz 1961, s. 55-82; Arszyński 1970, s. 7-139; 2016; Horbacz 1996, s. 167-181; Hennrich 2003, s. 24-52; Wasik 2016). Odkrycie w Starym Rypinie późnośredniowiecznego pieca z całym wsadem pozwoliło uściślić niektóre technologiczne niuanse, istotne dla rekonstruowanego procesu produkcyjnego (Lewandowska, w druku).

Ze względu na unikalność, a także wyjątkowo dobry stan zachowania pieca, warto przybliżyć ten późnośredniowieczny obiekt o charakterze przemysłowym (ryc. 3). Zachowany był do wysokości 1,2 $\mathrm{m}$ i miał prostokątny zarys o wymiarach zewnętrznych wynoszących na dłuższej osi (wschód-zachód) 6,5 m (mur B), wraz z przyporą $7 \mathrm{~m}$, na krótszej (północ-południe) 5,4 m (mur C). Wnętrze pieca na dłuższej osi (wschód-zachód) liczyło 5,1 m (mur B), na krótszej (północ-południe) 4,7 m (mur C), natomiast szerokość ścian 0,6-0,7 m. Wewnętrzna powierzchnia wynosiła około $24 \mathrm{~m}^{2}$. Piec był zagłębiony w ziemię, zbudowany z niewypalonych cegieł, łączonych spoiwem glinianym. Część z nich, w wyniku działania wysokiej temperatury częściowo się wypaliła, zwłaszcza w sektorze komory ogniowej i przy wejściu do niej. Niestety, ze względu na to, że układ cegiel, z których wzniesiono piec nie odpowiada klasyfikacjom przyjętym w literaturze, nie można określić wątku, w jakim zbudowano jego ściany. Wejście do komory sklepione było półkoliście, o czym świadczy układ cegieł, w tym widoczny opór łęku. Północno-zachodni narożnik pieca (pod murem określonym jako C) dodatkowo wzmocniono podkładem z cegieł (ryc. 3, 5). W ścianie wschodniej (określonej jako mur A) znajdowały się prawdopodobnie dwa otwory ogniowe - paleniska, z których jeden został odsłonięty podczas badań wykopaliskowych w 2015 roku. Zadokumentowano również profil południowy północnej komory, tym samym profil północny środkowej, największej platformy na cegły do wypału. Środkowa część pieca, jak i druga jego komora celowo nie zostały wyeksplorowane, ponieważ to wiązałaby się z dużą destrukcją tego wyjątkowego znaleziska. Dlatego też obserwacje dotyczące budowy pieca poczyniono na podstawie badań jednej

${ }^{2}$ Prace te były finansowane ze środków Wojewódzkiego Urzędu Ochrony Zabytków w Toruniu oraz Muzeum Ziemi Dobrzyńskiej w Rypinie. W 2017 roku prowadzono badania w obrębie dwóch wykopów (6/17 i 7/17); ich wstępne wyniki zaprezentowano w niniejszym artykule. 


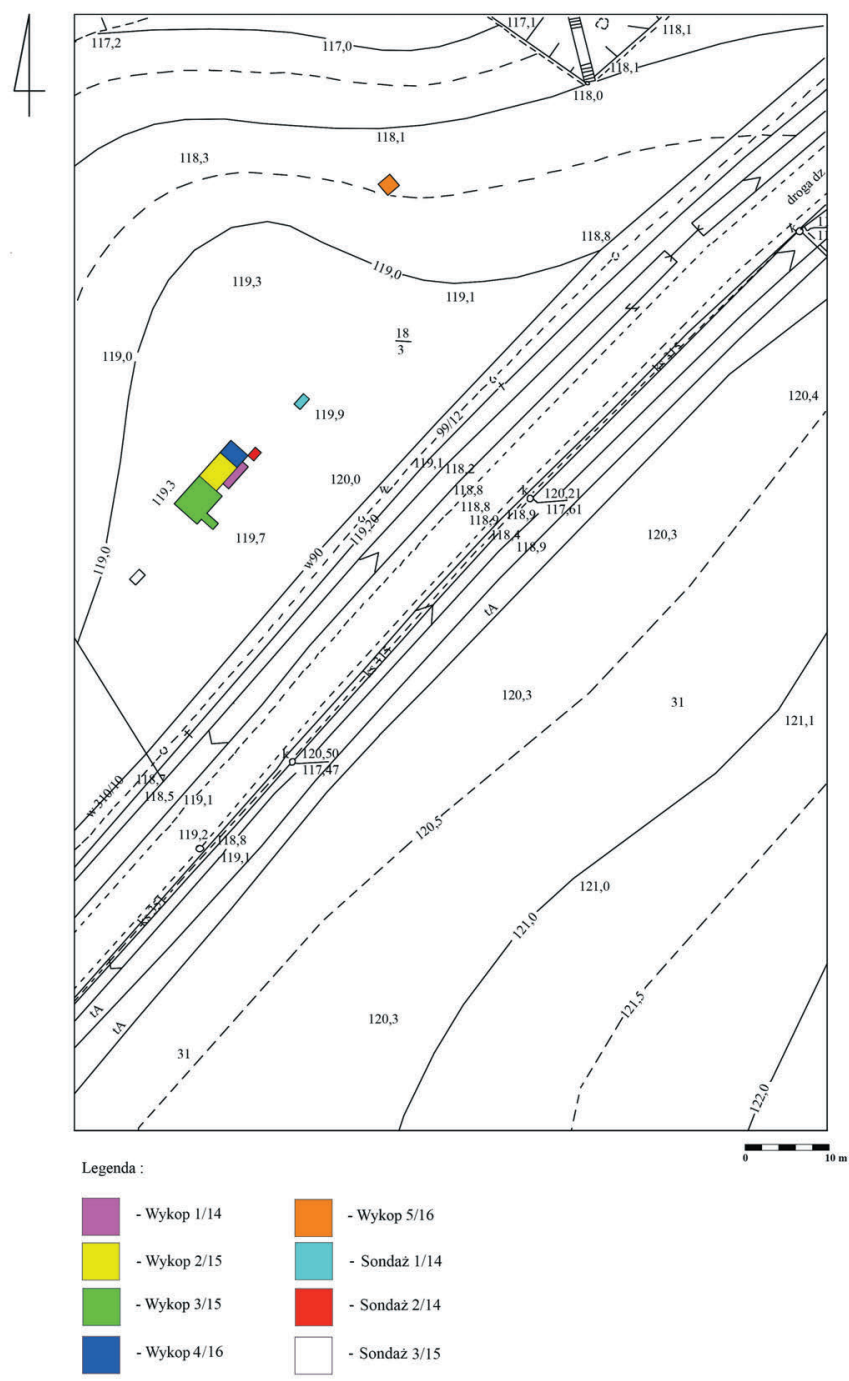

Ryc. 2. Stary Rypin, woj. kujawsko-pomorskie, stanowisko 4. Rozmieszczenie wykopów badawczych z lat 2014-2016 (oprac. J. Lewandowska, J. Zieliński, F. Marciniak)

Fig. 2. Stary Rypin, Kuyavian-Pomeranian Voivodeship, site 4. Location of trenches from 2014-2016 (edited by J. Lewandowska, J. Zieliński, F. Marciniak)

komory - północnej, zakładając, że komora południowa była taka sama lub różniła się tylko nieznacznie. Styk murów określonych jako A i B został wzmocniony szkarpą zlokalizowaną w narożniku założenia tworząc w ten sposób wyraźnie odcinającą się partię czołową. Do budowy tego zabezpieczenia użyto, w odróżnieniu od pozostałej części pieca, kamieni (ryc. 6). Dookoła wewnętrznych ścian pieca znajdowały się ceglane ławy (platformy) o szerokości około 0,5 m (ryc. 7). 


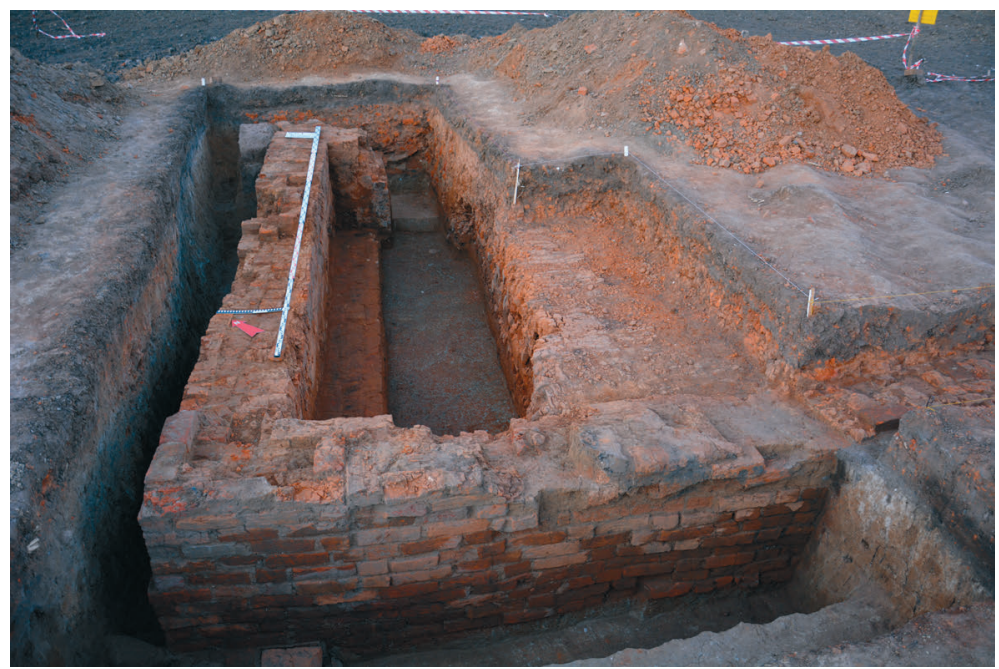

Ryc. 3. Stary Rypin, woj. kujawsko-pomorskie, stanowisko 4. Późnośredniowieczny piec do wypału ceramiki budowlanej - widok od zachodu (fot. J. Lewandowska)

Fig. 3. Stary Rypin, Kuyavian-Pomeranian Voivodeship, site 4. Late medieval kiln for construction ceramics firing - view from the west (photo by J. Lewandowska)

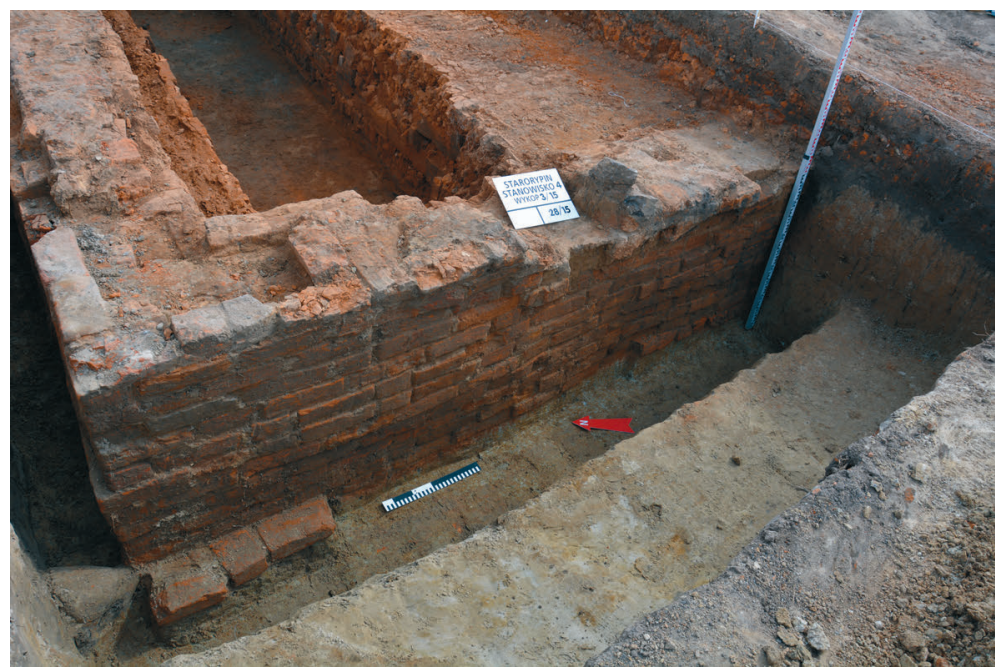

Ryc. 4. Stary Rypin, woj. kujawsko-pomorskie, stanowisko 4. Późnośredniowieczny piec do wypału ceramiki budowlanej - lico zewnętrzne muru C; wykop 3/15 (fot. J. Lewandowska)

Fig. 4. Stary Rypin, Kuyavian-Pomeranian Voivodeship, site 4. Late medieval kiln for construction ceramics firing - external face of the wall C; trench 3/15 (photo by J. Lewandowska) 


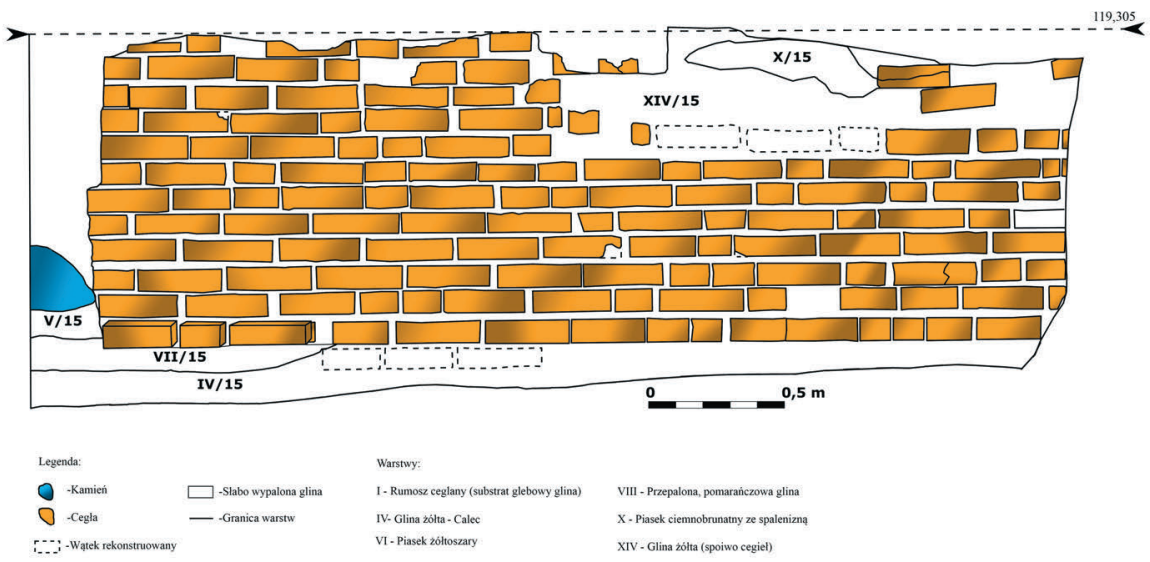

Ryc. 5. Stary Rypin, woj. kujawsko-pomorskie, stanowisko 4. Późnośredniowieczny piec do wypału ceramiki budowlanej - lico zewnętrzne muru C; wykop 3/15 (rys. A. Pawlik, oprac. F. Marciniak)

Fig. 5. Stary Rypin, Kuyavian-Pomeranian Voivodeship, site 4. Late medieval kiln for construction ceramics firing - external face of the wall C; trench 3/15 (drawing by A. Pawlik, edited by F. Marciniak)

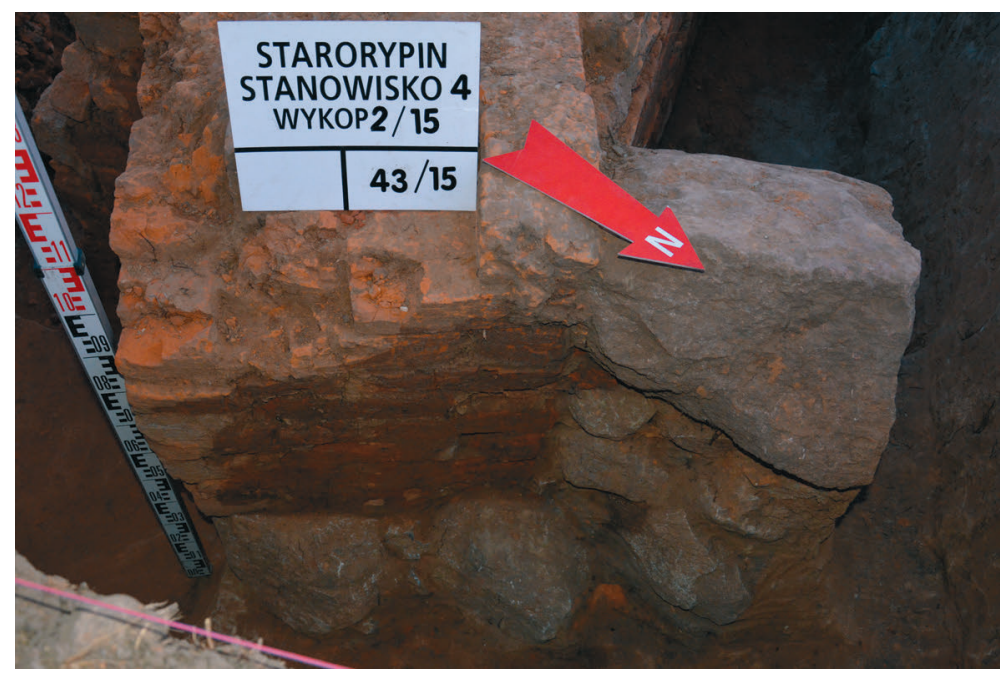

Ryc. 6. Stary Rypin, woj. kujawsko-pomorskie, stanowisko 4. Późnośredniowieczny piec do wypału ceramiki budowlanej - lico zewnętrzne muru A; wykop 2/14 (fot. A. Różański)

Fig. 6. Stary Rypin, Kuyavian-Pomeranian Voivodeship, site 4. Late medieval kiln for construction ceramics firing - external face of the wall A; trench 2/14 (photo by A. Różański) 


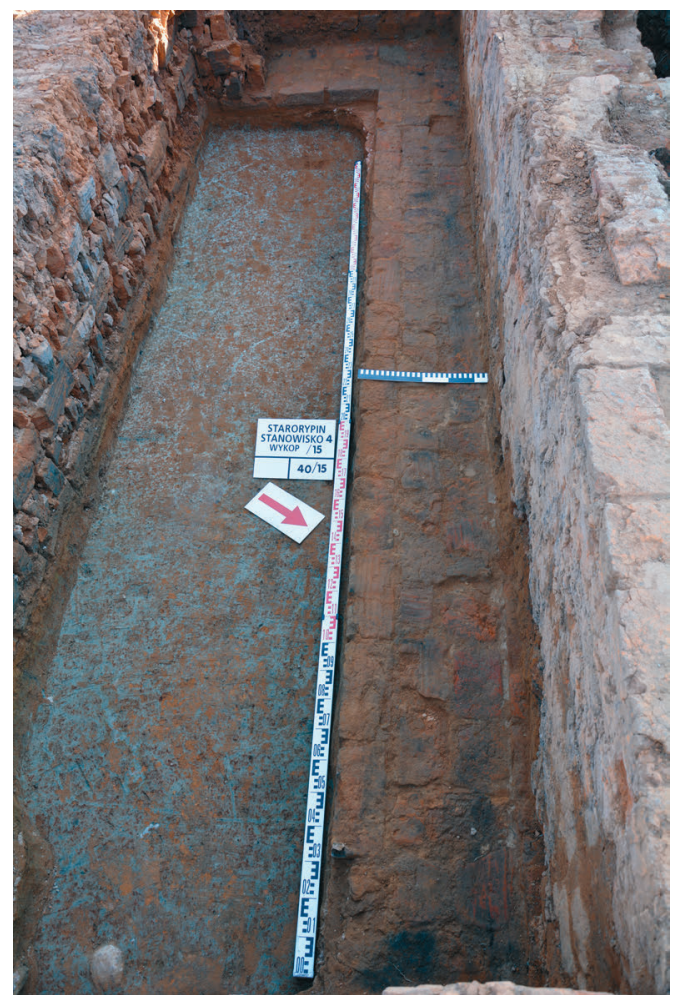

Ryc. 7. Stary Rypin, woj. kujawsko-pomorskie, stanowisko 4. Późnośredniowieczny piec do wypału ceramiki budowlanej - wnętrze komory północnej z widoczną platformą na cegły (fot. J. Lewandowska)

Fig. 7. Stary Rypin, Kuyavian-Pomeranian Voivodeship, site 4. Late medieval kiln for construction ceramics firing - interior of the northern chamber with visible platform for bricks (photo by J. Lewandowska)

Dodatkowa, większa platforma została umieszczona pomiędzy dwoma komorami ogniowymi. W obrębie platform zalegały cegły do wypalenia. W osi otworów ogniowych posadzkę stanowiła warstwa gliny, która pod wpływem wysokiej temperatury nabrała odpowiedniej twardości i wytrzymałości (ryc. 8).

Piec prawdopodobnie nie posiadał sklepienia nad całą powierzchnią zamknięty był tylko na czas wypału. To rozwiązanie miało także uzasadnienie praktyczne i mogło ułatwiać załadunek i wyładunek cegieł od góry. Analiza murów, a także sytuacja stratygraficzna wskazuja, że po ułożeniu surówki piec uszczelniono od góry gliną, odpadkami z poprzednich wypałów i zapewne jeszcze ziemią, zostawiając jednocześnie odpowiednią liczbę otworów dymowych.

Pomiędzy przygotowanymi do wypału cegłami, zalegającymi w piecu, zarejestrowano odstępy o szerokości od 1 do $4 \mathrm{~cm}$. W przekroju podłużnym przez wypełnioną platformę/ławę środkową, a także ławy boczne komory północnej, 


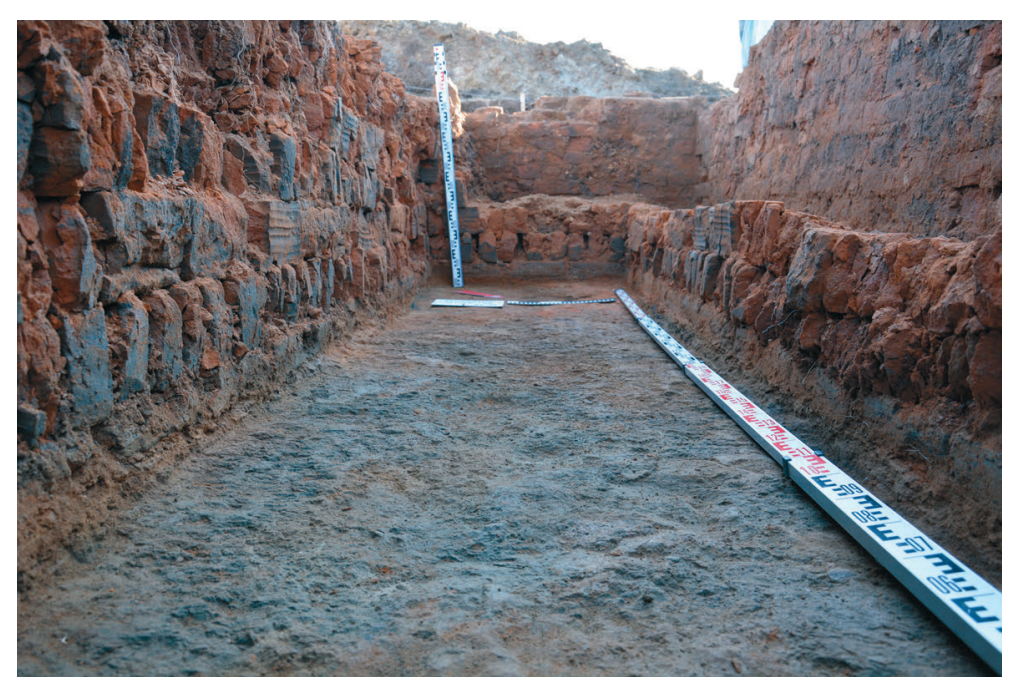

Ryc. 8. Stary Rypin, woj. kujawsko-pomorskie, stanowisko 4. Późnośredniowieczny piec do wypału ceramiki budowlanej - podłoga i ściany pieca w komorze północnej (fot. J. Lewandowska)

Fig. 8. Stary Rypin, Kuyavian-Pomeranian Voivodeship, site 4. Late medieval kiln for construction ceramics firing - floor and walls of the kiln in the northern chamber (photo by J. Lewandowska)

widoczny był układ tych cegieł na tzw. rolkę - w równoległych rzędach, naprzemiennie rozpoczynając od dołu główką do ognia, następnie układając podstawą i tak do samej góry. Mimo, że ułożenie cegieł na wszystkich poziomach nie zostało rozpoznane, było bardzo podobne do tego, które odnotowano w piecu z Narzymia koło Działdowa (ryc. 9) (Dethlefsen 1915, s. 12-14). Także pod względem konstrukcji pieców widoczne są duże zbieżności, choć ściany obiektu w Narzymiu zostały wykonane z kamieni i gliny, a w Starym Rypinie z cegieł, kamieni i gliny.

Na obecnym etapie badań można stwierdzić, że w opisywanym piecu produkowano tylko cegłę konstrukcyjną ${ }^{3}$. Nie natrafiono bowiem na jakiekolwiek ułamki cegły profilowanej czy dachówek. Nie można wykluczyć, że przed ułożeniem właściwej ławy do wypału cegieł, w piecu wypalano także wapienie, o czym mogą świadczyć śladowe ilości wapna zarejestrowane w północno-zachodniej jego części, pod ławą (ryc. 10). Na cegłach nie zachowały się znaki strycharzy czy właściciela cegielni, ani stemple. Zarejestrowano natomiast inne niecelowe ślady - odgniecenia, deformacje oraz odcisk kończyny sarny.

\footnotetext{
${ }^{3}$ Cegły pochodzące z opisywanego pieca miały wymiary 8-9×13-14×29-30 cm. Przykładowe wymiary cegieł z badań stanowiska w 2014 roku wynosiły: 8,3×14×30 cm (próba A), 8,6×13,5×31 cm (próba B), $8 \times 14 \times 29,5 \mathrm{~cm}$ (próba C); z badań w 2015 roku: 7,9×14×30,6 cm (próba P.1), 7,9×14,2×29,5 cm (próba P.3.1), 7,6×14×29,3 cm (próba P.3.2), $8 \times 14,2 \times 29,8 \mathrm{~cm}$ (próba P.3.3).
} 

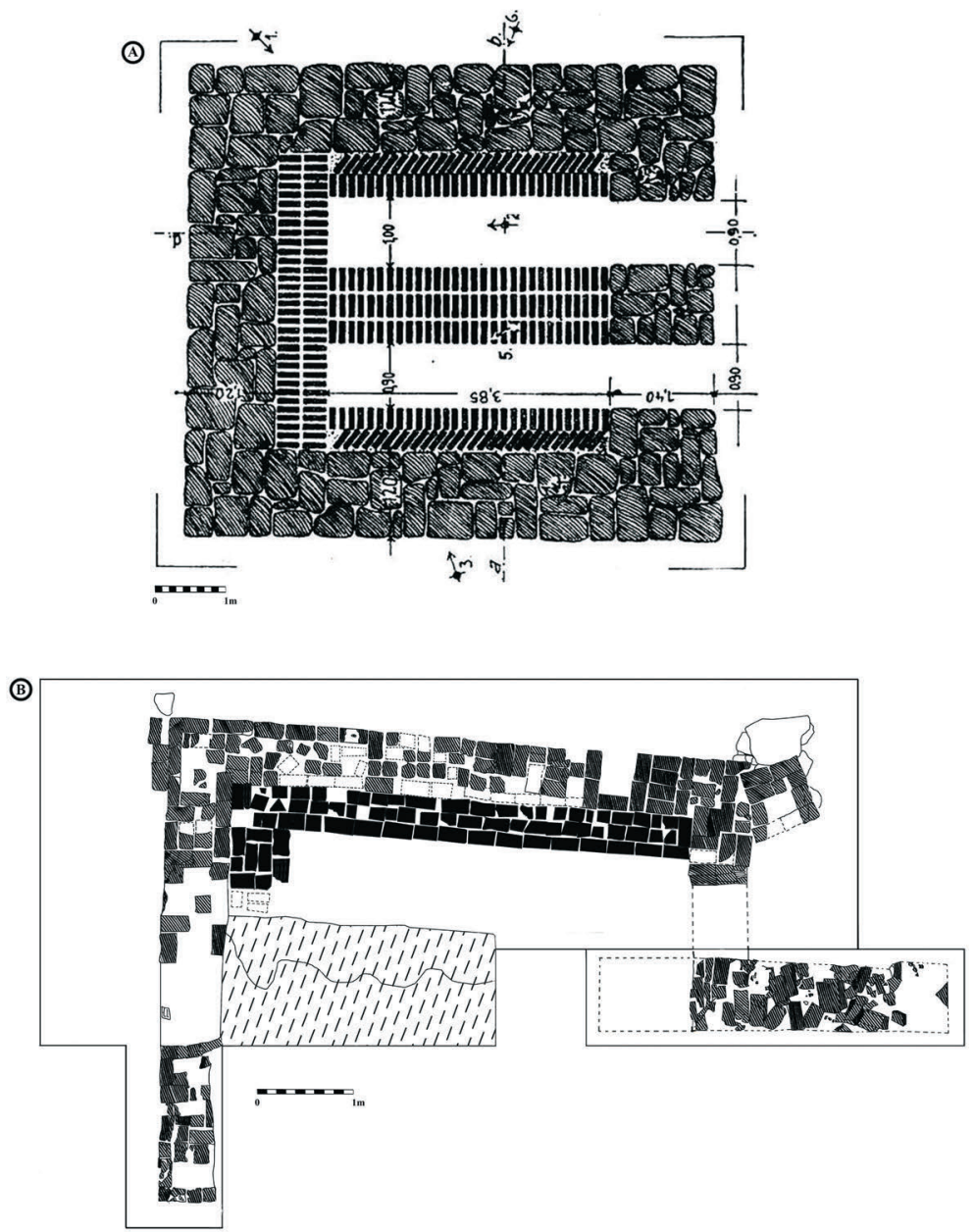

Ryc. 9. Rzuty poziome pieców w Narzymiu (A) i Starorypinie (B) (wg Dethlefsen 1915; oprac. J. Lewandowska)

Fig. 9. Plans of kilns in Narzym (A) and Starorypin (B) (after Dethlefsen 1915; edited by J. Lewandowska)

Według typologii średniowiecznych pieców ceglarskich zaproponowanej przez Claudię Hennrich (2003), piec ze Starego Rypina można zaliczyć do typu I b, posiadającego dwie komory ogniowe. Rezultat datowania luminescencyjnego trzech cegieł ${ }^{4}$ wskazuje, że mur, z którego pochodził materiał po raz ostatni poddany został działaniu wysokiej temperatury 705 lat temu, przy minimalnej niepewności

${ }^{4}$ Analizy wykonał zespół pod kierunkiem dr hab. Alicji Chruścińskiej, prof. UMK w Zakładzie Fizyki Półprzewodników i Fizyki Węgla Wydziału Fizyki, Astronomii i Informatyki Stosowanej Uniwersytetu Mikołaja Kopernika w Toruniu. 


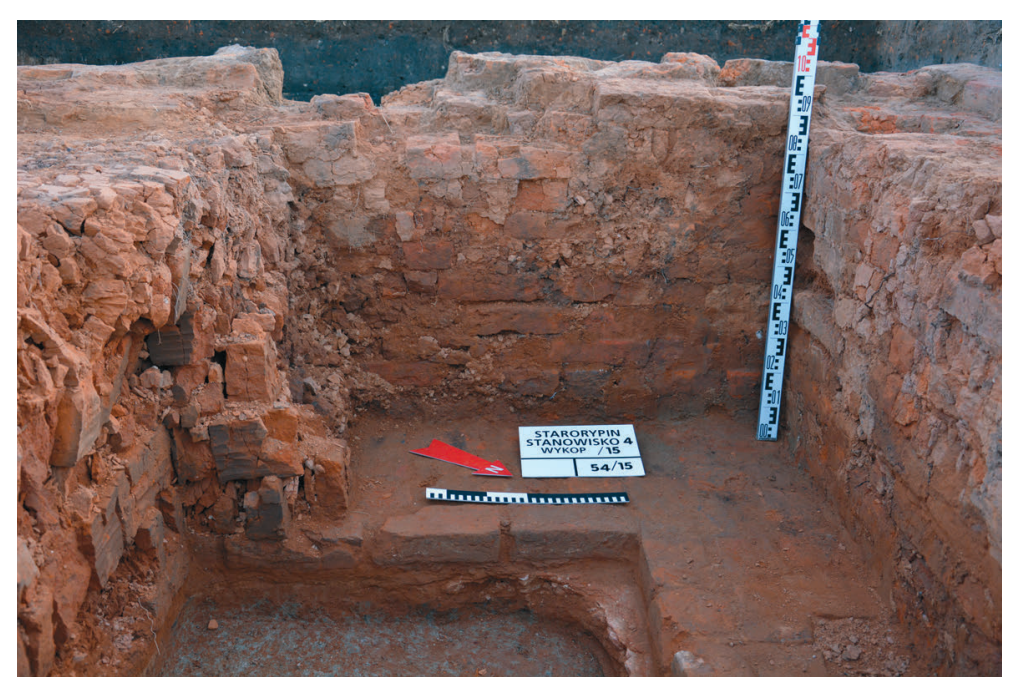

Ryc. 10. Stary Rypin, woj. kujawsko-pomorskie, stanowisko 4. Późnośredniowieczny piec do wypału ceramiki budowlanej - wewnętrzna ściana zachodnia komory północnej (fot. A. Różański)

Fig. 10. Stary Rypin, Kuyavian-Pomeranian Voivodeship, site 4. Late medieval kiln for construction ceramics firing - inner western wall of the northern chamber (photo by A. Różański)

tego oszacowania 41 lat (Chruścińska 2016; Chruścińska, Palczewski, Przegiętka, w druku). Natomiast datowanie ${ }^{14} \mathrm{C}$ węgla drzewnego pochodzącego z wejścia do komory północnej ${ }^{5}$ wskazują na czas $745 \pm 30$ BP (Goslar, w druku). Pozwala to datować piec ze Starego Rypina od końca XIII do połowy XIV wieku. Może to sugerować, że wypalano w nim cegły zarówno na potrzeby budowy obiektu mieszkalno-obronnego odkrytego na stanowisku 1, jak i kościoła Bożogrobców, którego lokalizacja obecnie nie jest znana (Lewandowska, w druku).

W 2016 roku rozpoznano wejście do późnośredniowiecznego pieca; stwierdzono, że wykorzystano obniżenie terenu, powstałe po wybraniu warstwy gliny, które dodatkowo wzmocnione było cegłami z poprzedniego wypału i prawdopodobnie drewnem (ryc. 11). W innym miejscu stanowiska 4 (wykop 5/16) natrafiono na fragment innego pieca, dużo młodszego; badania w obrębie tego obiektu kontynuowano w 2017 roku (ryc. 12, 13, 14). W wyniku tych prac odsłonięto trzy komory ogniowe oraz platformy na cegły. Ze względu na niewielki zakres prac nie sposób wskazać faktyczne wymiary pieca i liczby wszystkich komór ogniowych oraz platform przeznaczonych do wypału cegieł. Platformy te, o szerokości 0,7 m i grubości $0,08-0,10 \mathrm{~m}$ zostały zbudowane pierwotnie z gliny i pojedynczych, niewypalonych cegieł, które po kontakcie z wysoką temperaturą stwardniały.

\footnotetext{
${ }^{5}$ Analizy wykonał zespół pod kierunkiem prof. dr. hab. Tomasza Goslara, w Poznańskim Laboratorium Radiowęglowym.
} 


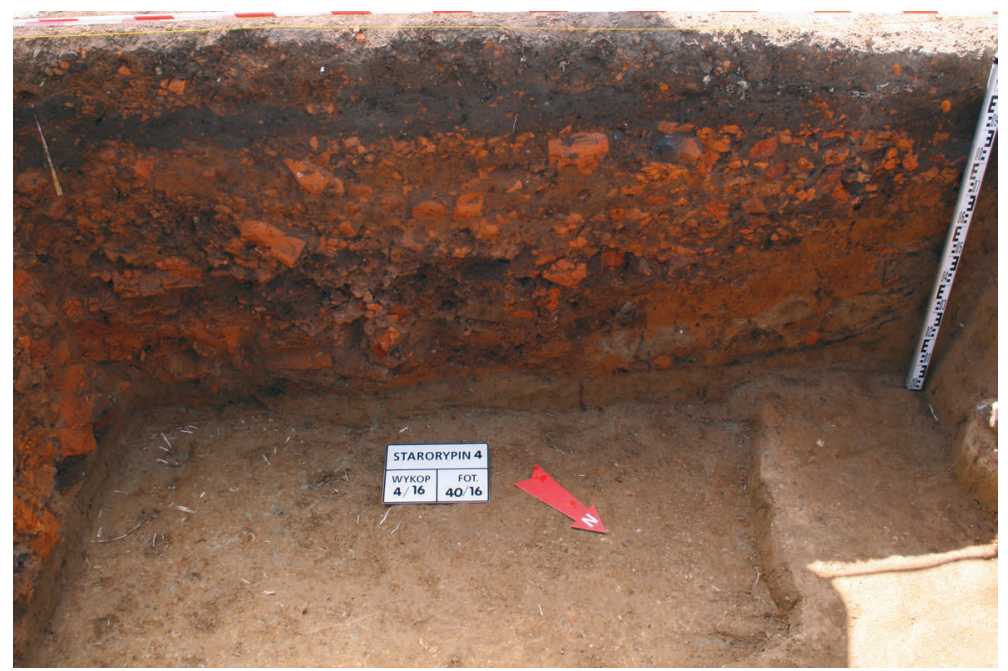

Ryc. 11. Stary Rypin, woj. kujawsko-pomorskie, stanowisko 4. Późnośredniowieczny piec do wypału ceramiki budowlanej - pozostałości wejścia; wykop 4/16, profil zachodni (fot. J. Lewandowska)

Fig. 11 Stary Rypin, Kuyavian-Pomeranian Voivodeship, site 4. Late medieval kiln for construction ceramics firing - remains of the entrance; trench $4 / 16$, western section (photo by J. Lewandowska)

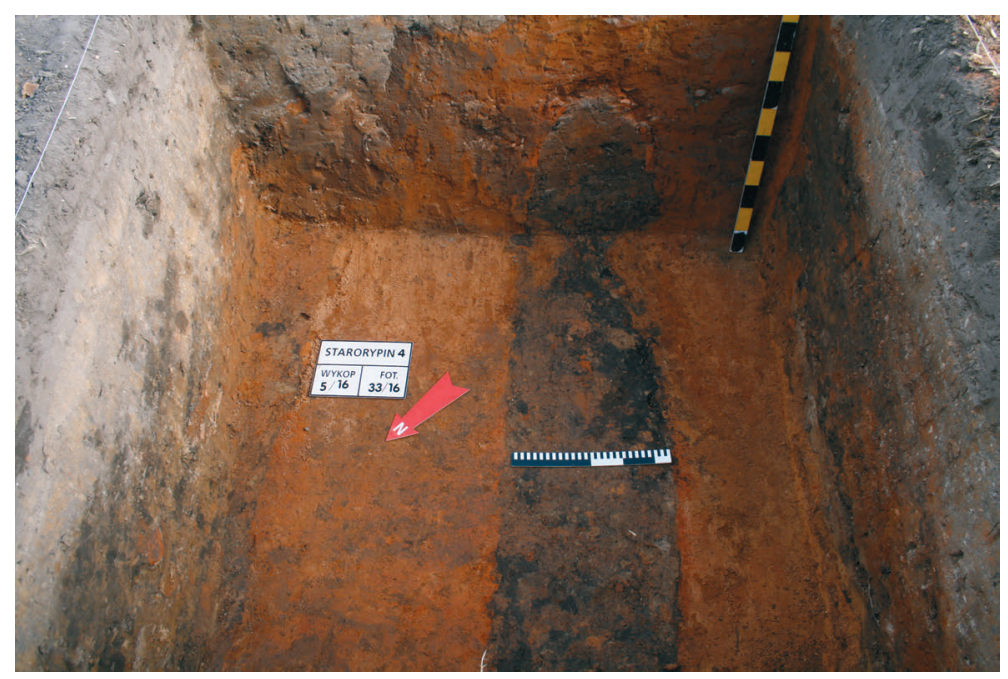

Ryc. 12. Stary Rypin, woj. kujawsko-pomorskie, stanowisko 4. Pozostałości nowożytnego pieca do wypału ceramiki budowlanej; wykop 5/16 (fot. J. Lewandowska)

Fig. 12. Stary Rypin, Kuyavian-Pomeranian Voivodeship, site 4. Remains of Post-medieval kiln for construction ceramics firing; trench 5/16 (photo by J. Lewandowska) 


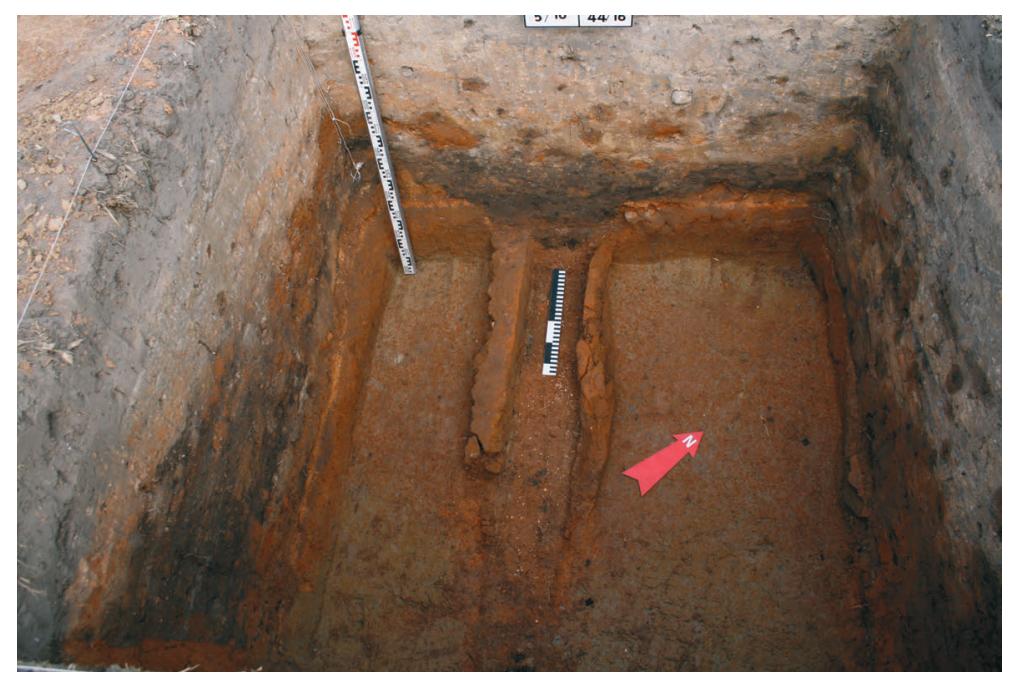

Ryc. 13. Stary Rypin, woj. kujawsko-pomorskie, stanowisko 4. Pozostałości nowożytnego pieca do wypału ceramiki budowlanej; wykop 5/16 (fot. J. Lewandowska)

Fig. 13. Stary Rypin, Kuyavian-Pomeranian Voivodeship, site 4. Remains of Post-medieval kiln for construction ceramics firing; trench 5/16 (photo by J. Lewandowska)

Odsłonięta w dwóch wykopach (5/16 i 6/17) południowo-zachodnia część ściany pieca zawierała trzy otwory, które funkcjonalnie można łączyć z ujściem komór ogniowych. Od wnętrza pieca miały one szerokość około 0,45 m, natomiast wysokość w granicach 0,65-0,70 m. Po zewnętrznej stronie ściany, wielkości te były mniejsze - maksymalna szerokość wynosiła 0,39 m, wysokość zaś od 0,62 do 0,69 m. Do budowy tej części pieca użyto cegieł, niestety, nie zachowały się one w całości, co pozwala na wskazanie jedynie szacunkowych ich wymiarów: wysokości wynoszącej 6-6,3 cm i szerokości główki 13-13,3 cm. Komory ogniowe miały natomiast szerokość około 0,6 cm. Długość ścian pieca, wielkość platform i komór ogniowych nie jest dotychczas rozpoznana. Nie odsłonięto też frontowej ściany z czeluściami palenisk; znane ze źródeł pisanych piece zawierały najczęściej trzy czeluście (Pietrzak 2013, s. 200). Opisany piec, podobnie jak średniowieczny, nie posiadał sklepienia, a po ułożeniu surówki był uszczelniany glina, zasypywany ziemią, z pozostawieniem odpowiedniej ilości otworów dymowych. Na obecnym etapie badań można wskazać duże podobieństwo pieca ze Starego Rypina do obiektu odkrytego w Nakonowie Starym na Kujawach, datowanego na XVIII-XIX wiek (Pietrzak 2013, s. 202). Oba zostały wycięte w podłożu z gliny, która po kontakcie z wysoką temperaturą utworzyła utwardzone ściany (ryc. 15, 16).

Podczas badań w 2017 roku na stanowisku 4 w Starym Rypinie (w wykopie 7/17) odsłonięto fragment kolejnego nowożytnego pieca, także utworzonego poprzez wkopanie w gliniaste podłoże, które po wypaleniu utworzyło ściany pieca (ryc. 17). Być może w wyniku dalszych badań uda się wyjaśnić kwestie 

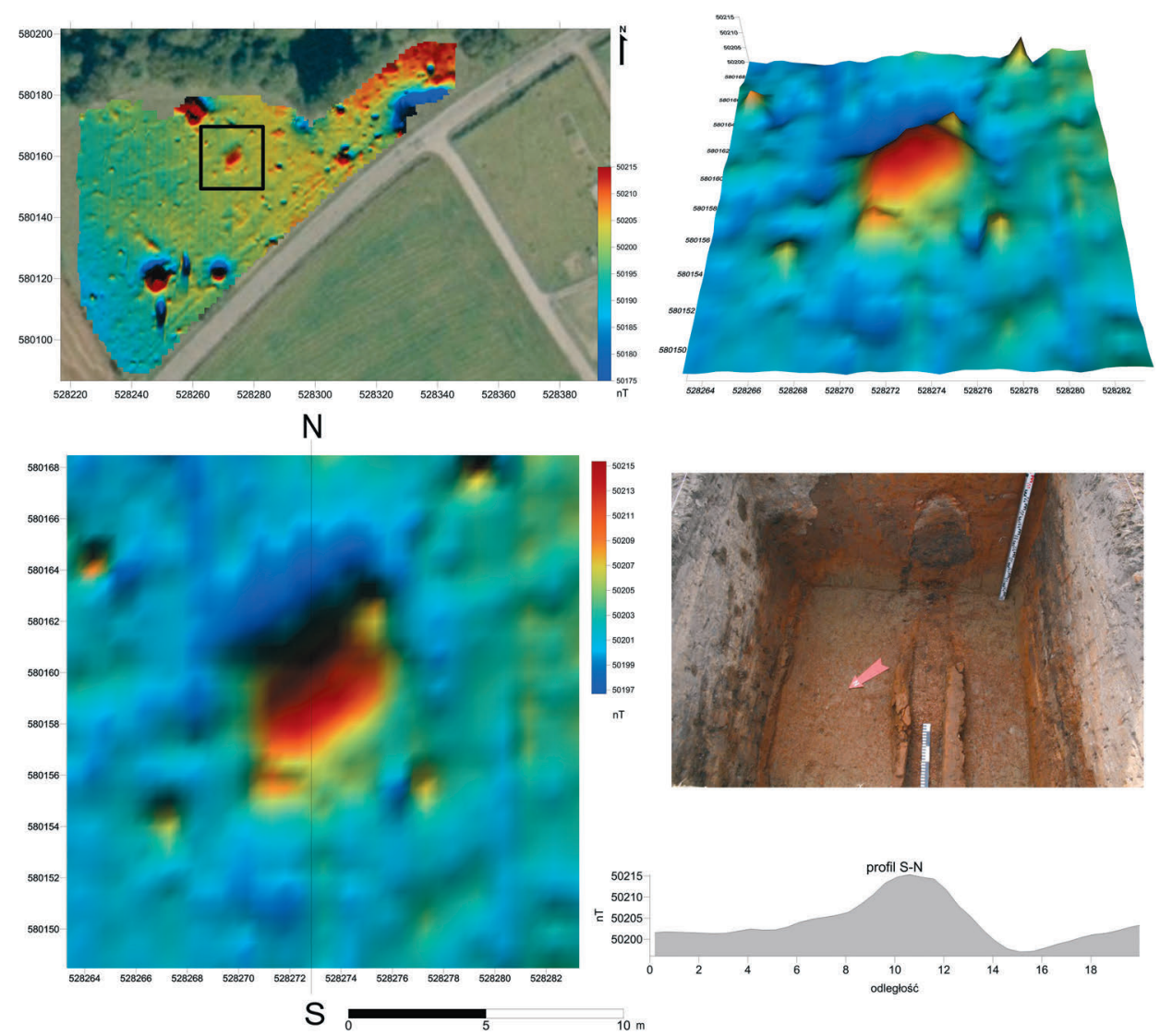

Ryc. 14. Stary Rypin, woj. kujawsko-pomorskie, stanowisko 4. Wykop 5/16 - weryfikacja wybranej anomalii z badań nieinwazyjnych z fragmentem pieca nowożytnego (oprac. W. Małkowski)

Fig. 14. Stary Rypin, Kuyavian-Pomeranian Voivodeship, Site 4. Trench 5/16 - verification of selected anomaly from non-invasive research with a fragment of a Post-medieval kiln (edited by W. Małkowski)

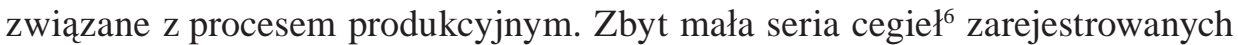
w dwóch opisanych piecach (odkrytych w wykopach 5/16, 6/17 i 7/17) uniemożliwia odniesienie się do ustaleń chronologicznych (Kajzer 1984, rys. 1, s. 170).

Wszystkie odkryte dotychczas na stanowisku 4 piece zapewne można wiązać z wytwórczością na lokalne potrzeby mieszkańców Starego Rypina. Stwarzało to zaplecze surowcowe w postaci cegły konstrukcyjnej dla budownictwa murowanego zarówno w późnym średniowieczu, jak i nowożytności. Nie sposób wskazać w związku z jaką inwestycją produkowano cegły w tym miejscu. Wyroby

\footnotetext{
${ }^{6}$ Najlepiej zachowane cegły użyte do konstrukcji komory ogniowej pieca w wykopie 7/17 wynosiły: $6 \times 13,4 \times 27 \mathrm{~cm}$ (próba P/5/17).
} 


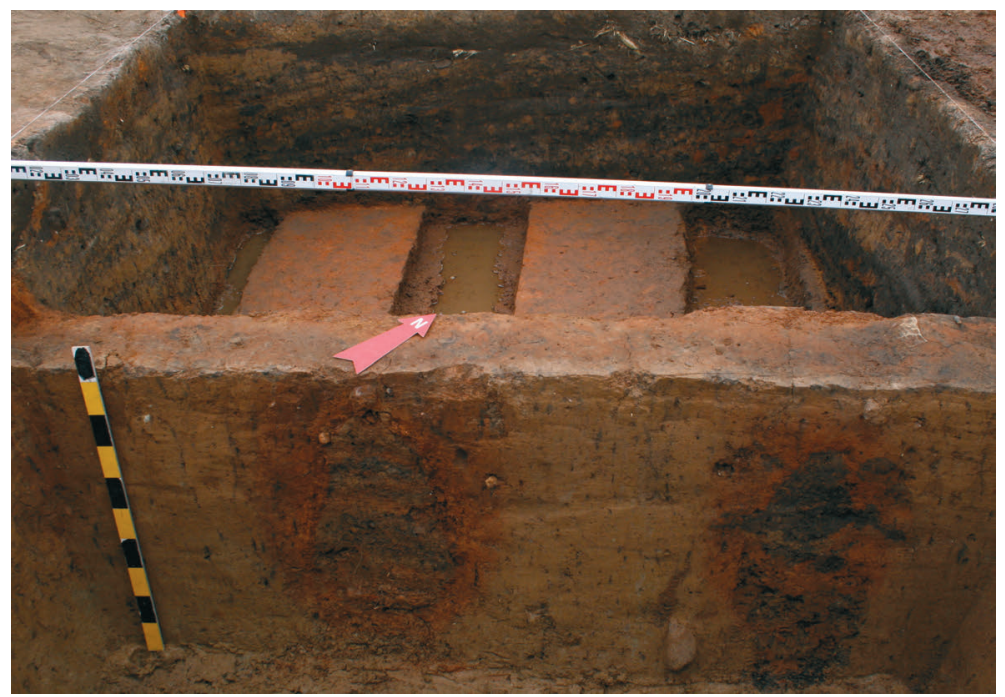

Ryc. 15. Stary Rypin, woj. kujawsko-pomorskie, stanowisko 4. Pozostałości nowożytnego pieca do wypału ceramiki budowlanej; wykop 6/17 (fot. J. Lewandowska)

Fig. 15. Stary Rypin, Kuyavian-Pomeranian Voivodeship, site 4. Remains of Post-medieval kiln for construction ceramics firing; trench 6/17 (photo by J. Lewandowska)

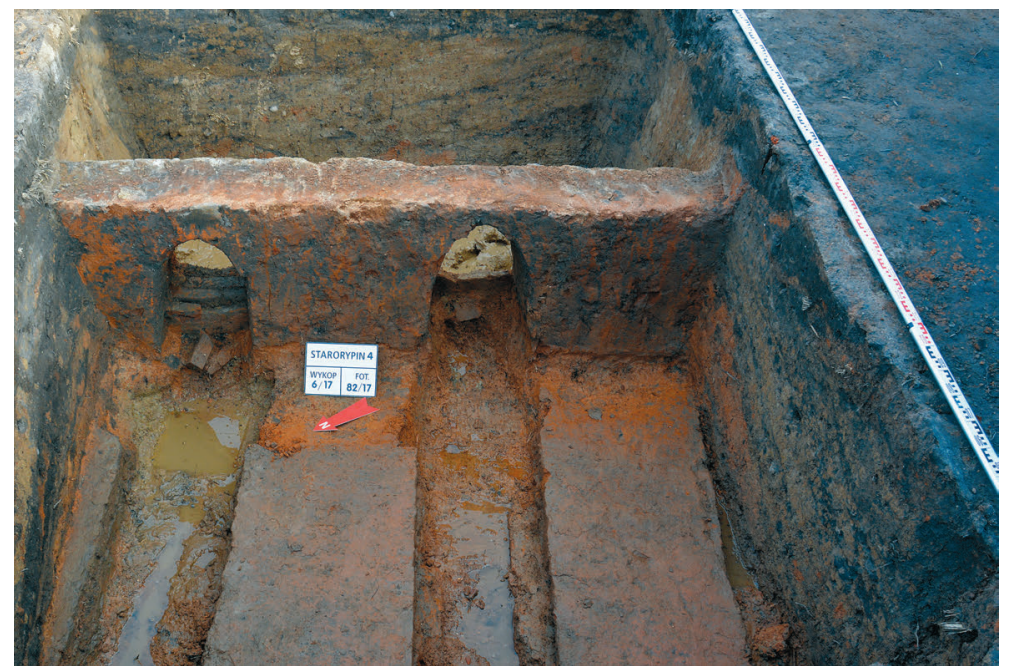

Ryc. 16. Stary Rypin, woj. kujawsko-pomorskie, stanowisko 4. Pozostałości nowożytnego pieca do wypału ceramiki budowlanej; wykop 6/17 (fot. J. Lewandowska)

Fig. 16. Stary Rypin, Kuyavian-Pomeranian Voivodeship, site 4. Remains of Post-medieval kiln for construction ceramics firing; trench 6/17 (photo by J. Lewandowska) 


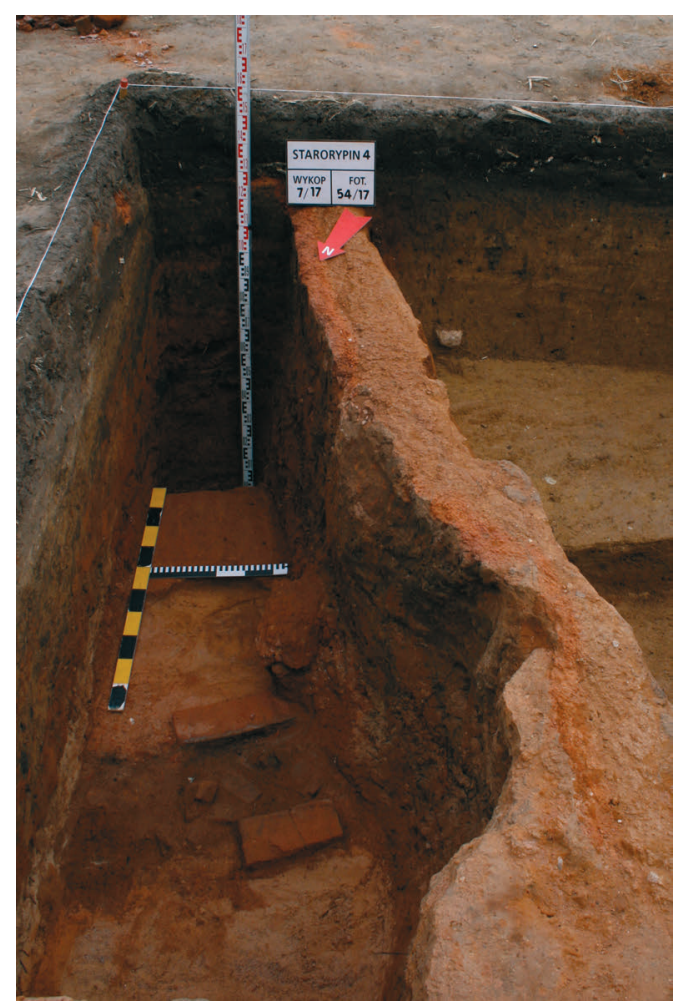

Ryc. 17. Stary Rypin, woj. kujawsko-pomorskie, stanowisko 4. Pozostałości nowożytnego pieca do wypału ceramiki budowlanej; wykop 7/17 (fot. J. Lewandowska)

Fig. 17. Stary Rypin, Kuyavian-Pomeranian Voivodeship, site 4. Remains of Post-medieval kiln for construction ceramics firing; trench 7/17 (photo by J. Lewandowska)

pochodzące z nowożytnych pieców mogły zostać wykorzystane podczas rozbudowy obiektów dworsko-folwarcznych (Celińska, Gałkowski 2006, s. 303-322), jednak kwerenda źródeł pisanych nie wyjaśnia tych kwestii. Nie znany jest także fundator tych prac. Warto podkreślić, że w piecu o metryce późnośredniowiecznej nie dokończono wypału, pozostawiając go z całym wsadem, natomiast piece nowożytne po wyjęciu wypalonych cegieł, najprawdopodobniej po zakończonej inwestycji, zasypano.

Odkrycie trzech pieców o różnej chronologii jest dowodem na tradycję tego miejsca, zapewne wynikającą z dostępności i jakości surowca. Badania geomorfologiczne ${ }^{7}$ potwierdziły duże pokłady gliny znajdujące się na obszarze całego stanowiska 4. Glina ilasta, o szczególnie dobrych właściwościach plastycznych, zalega poniżej gliny budującej powierzchnię wysoczyzny morenowej, na której położony jest Stary Rypin oraz pomiędzy warstwami piaszczystymi. Poza tym

\footnotetext{
${ }^{7}$ Badania przeprowadzono wiosną 2016 roku.
} 


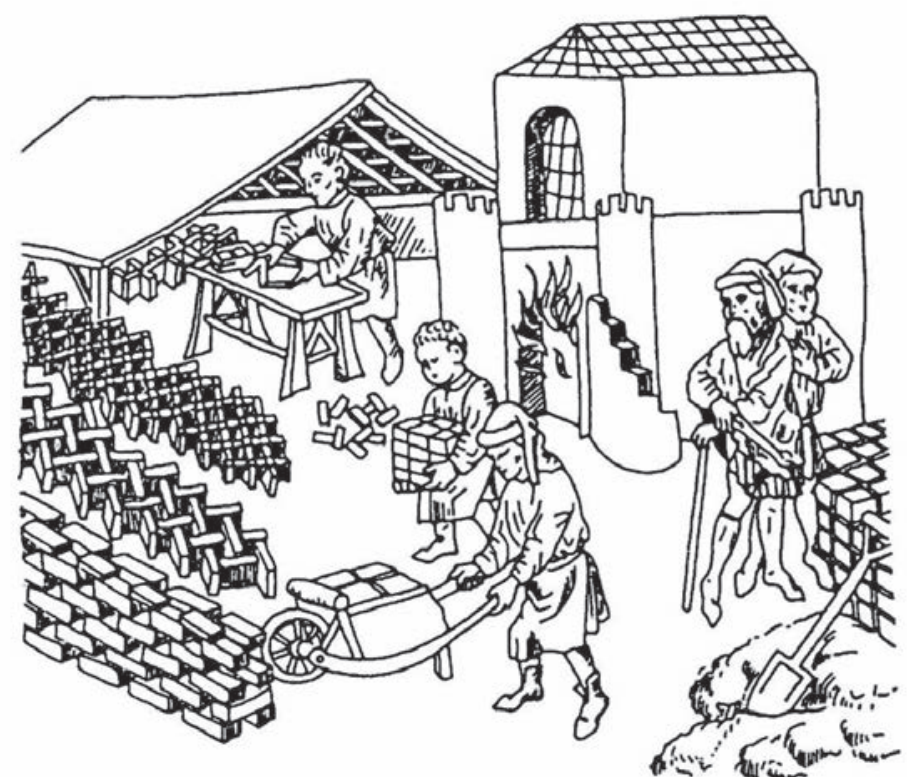

Ryc. 18. Widok średniowiecznej cegielni (wg Binding 2004)

Fig. 18. View of medieval brickyard (after Binding 2004)

w kilku miejscach, w obrębie współczesnym wejściu do grodziska, znajdują się dawne wyrobiska tego surowca w postaci nisz przedzielonych grzędami (hałdami górniczymi) o wysokości do 2 m (Weckwerth, w druku). Każdy z pieców odkryty na stanowisku 4 w Starym Rypinie był inaczej zorientowany względem stron świata. Ta celowa lokalizacja wynikała zapewne z obserwacji wiatrów dominujących w okresie letnim, w celu wykorzystania ich siły do wytworzenia cugu. Wszystkie zbadane dotychczas w różnym stopniu piece ze Starego Rypina zostały wkopane $\mathrm{w}$ gliniaste podłoże, z zastosowaniem podobnych zasad produkcyjnych. Były to obiekty stałe, wielokrotnego użytku, zasklepione tylko na czas wypału. Dotychczas na opisywanym stanowisku nie odkryto śladów wypału cegły w układanych z surówki mielerzach. Być może zasadna jest teza Janusza Pietrzaka, przytoczona za Józefem Galerem, że: „,...] oba systemy wymagają od ceglarza podobnych umiejętności, zarazem jednak piec stały pozwalał na lepsze wykorzystanie opalanej przestrzeni, powstaje w nim też mniej złomu i niedopału, a sama cegła jest lepsza” (Pietrzak 2013, s. 214).

Cegielnia w Starym Rypinie zajmowała pierwotnie przypuszczalnie bardzo dużą przestrzeń potrzebną między innymi na leżakowanie gliny, suszenie cegieł przed wypałem itp. Oprócz pieców znajdowały się tam zapewne inne obiekty, w tym glinianki i drewniane szopy. Zdaniem Andrzeja Wyrobisza łacińska nazwa cegielni - horreum laterum - może wskazywać, że właśnie drewniane szopy były elementem odróżniającym cegielnie w przestrzeni (Wyrobisz 1961, 
s. 68). Zapewne drewniana zabudowa towarzyszyła również piecom stałym, nad którymi - jak wynika z wielu źródeł pisanych - znajdowały się wiaty, zabezpieczające przed wilgocią (Pietrzak 2013, s. 204-205). Niezbędne wyposażenie cegielni stanowiły narzędzia - łopaty, taczki, wózki, konwie. Niestety, na badanym stanowisku nie natrafiono na ich pozostałości.

Na podstawie wyników badań wykopaliskowych można sądzić, że działający w Starym Rypinie fabricator, specjalizujący się w wytwarzaniu cegieł, stosował zbiegi niezbędne do przeprowadzenia procesu produkcyjnego (wykopanie i przygotowanie gliny, wyrób cegieł, wypał itd.), logiczny podział przestrzeni i pracy, wymagającej dużej wiedzy i doświadczenia (ryc. 18). Zarówno z rezultatów tych badań, jak i literatury przedmiotu wynika, że technologie wyrobu cegieł w średniowieczu i nowożytności nie różniły się w znaczący sposób. Jedynie w przypadku tej ostatniej proces formowania cegieł był częściowo zmechanizowany oraz - być może stosowano inny opał (Horbacz 1996, s. 169).

\section{Literatura}

Arszyński M.

1970 Technika i organizacja budownictwa ceglanego w Polsce w końcu XIV w. i 1 połowie XV wieku, [w:] Studia i materiały z historii kultury materialnej, t. 39, Studia z dziejów rzemiosła i przemysłu, t. 9, red. Z. Kamieńska, Wrocław, s. 7-139.

2016 Organizacja i technika średniowiecznego budownictwa ceglanego w Prusach w kontekście europejskim, Malbork.

Binding G.

2004 Medieval building techniques, Stroud.

Celińska E., Gałkowski P.

2006 Starorypin. Zespót dworski, [w:] Materiały do dziejów rezydencji w Polsce. Ziemia dobrzyńska, t. 2, cz. 3, red. P. Gałkowski, S. Kunikowski, Włocławek, s. 303-322.

Chruścińska A.

2016 Określenie metodą luminescencyjną wieku prób cegły pochodzących ze stanowiska archeologicznego w Starym Rypinie. Raport z wykonania prac badawczych w ramach umowy nr 427/15 z dnia 30.06.2015 r., maszynopis w archiwum Muzeum Ziemi Dobrzyńskiej w Rypinie, Toruń.

Chruścińska A., Palczewski P., Przegiętka K. R.

w druku Datowanie luminescencyjne cegieł pochodzących ze stanowiska 4 w Starym Rypinie, [w:] Późnośredniowieczny kompleks osadniczy w Starym Rypinie, red. J. Lewandowska, Toruń.

Dethlefsen R.

1915 Ein mittelalterlicher Ziegelofen, Die Denkmalpflege, R. 17, s. 12-14. 
Goslar T.

w druku Określenie wieku bezwzględnego próbek ze Starego Rypina, [w:] Późnośredniowieczny kompleks osadniczy w Starym Rypinie, red. J. Lewandowska, Toruń.

Hennrich C.

2003 Mittelalterliche Ziegelbrenntechniken, [w:] Backsteintechnologien in Mittelalter und Neuzeit, Studien zur Backsteinarchitektur 4, red. E. Badstübner, D. Schumann, Berlin, s. 24-52.

Horbacz T. J.

1996 Teoria a doświadczenie. Wokót kwestii zwiqzanych z produkcja cegły w średniowieczu, Archaeologia Historica Polona, t. 3, s. 167-181.

Kajzer L.

1984 Wstęp do badań archeologiczno-architektonicznych, Łódź.

Lewandowska J.

2011 Średniowieczny kompleks osadniczy w Starorypinie, gm. Rypin, woj. kujawsko-pomorskie w świetle badań archeologicznych prowadzonych w latach 2007-2009, [w:] XVII Sesja Pomorzoznawcza, t. 1: Od epoki kamienia do wczesnego średniowiecza, red. M. Fudziński, H. Paner, Gdańsk, s. 541-552.

2016 Odkryte skarby, nierozwiqzane zagadki i nowe perspektywy badawcze Starego Rypina, [w:] Dziedzictwo archeologiczne pólnocnej części ziemi dobrzyńskiej, red. J. Lewandowska, Toruń, s. 125-148.

w druku Późnośredniowieczne osadnictwo na stanowisku 4. Cegielnia, [w:] Późnośredniowieczny kompleks osadniczy w Starym Rypinie, red. J. Lewandowska, Toruń.

Lewandowska J., Szymkowicz A.

w druku Osada ludności kultury pomorskiej odkryta na wielokulturowym stanowisku numer 3 w miejscowości Starorypin, gm. Rypin, woj. kujawsko-pomorskie, Rocznik Muzeum Ziemi Dobrzyńskiej w Rypinie, t. 3.

Pietrzak J.

2013 Nowożytne budownictwo przemysłowe w dobrach biskupich na Mazowszu, Łódź.

Weckwerth P.

w druku Charakterystyka geomorfologiczna obszaru Starego Rypina, [w:] Późnośredniowieczny kompleks osadniczy w Starym Rypinie, red. J. Lewandowska, Toruń.

Wasik B.

2016 Budownictwo zamkowe na ziemi chetmińskiej (od XIII do XV wieku), Toruń. Wyrobisz A.

1961 Średniowieczne cegielnie $w$ większych ośrodkach miejskich $w$ Polsce, [w:] Studia i materiały z historii kultury materialnej, t. 10, Studia z dziejów rzemiosła i przemysłu, t. 1, red. Z. Kamieńska, Wrocław, s. 55-82. 


\section{REMAINS OF A BRICKYARD IN STARY RYPIN}

Summary

Archaeological excavations on site 4 in Starorypin Prywatny (Rypin commune, Kuyavian-Pomeranian Voivodeship), carried out to a various degree in 2014-2017, aimed at clarification of function of this place, which was used as a settlement in the early Middle Ages, which is evidenced by presence of economic pits with pottery fragments and animal bone remains. In the late Middle Ages and in the Post-medieval period a brickyard operated here.

A late medieval brick kiln with entire charge was unearthed on the site. It was dug into the ground, built of unfired bricks, joined by clay binder. It was rectangular in plan and had two fire chambers, inside were platforms on which bricks for firing were placed. Probably the kiln did not have a vault over its entire surface, which had also a practical justification and could have facilitated loading and unloading bricks from the top. From the territory of Poland a kiln of similar construction is known from Narzym near Działdowo. It was also dug into the ground, had a rectangular outline, two fire openings, and consequently two flues. The walls of this kiln were, however, made of stone. According to the typology of medieval brick kilns proposed by Claudia Hennrich (2003), the kiln of Stary Rypin can be classified as type I b, having two fire chambers.

The bricks luminescence dating results indicate that the wall from which the dating material originated for the last time was exposed to high temperatures 705 years ago, with a minimum uncertainty of this estimation 41 years. In contrast, the radiocarbon dating of charcoal samples from the entrance to one of the chambers (north) indicates 745 $\pm 30 \mathrm{BP}$. It is difficult to determine whether it was a brickyard erected for the purpose of a specific investment in its immediate vicinity or whether it was built independently of the construction site. The dating of the kiln may suggest that the bricks were produced here both for the construction of a dwelling-defence building, the remains of which were discovered on the site, as well as the church of the Order of the Holy Sepulchre of currently unknown location.

On site 4 in Stary Rypin, two more kilns were found, much younger - preliminarily dated to the $19^{\text {th }}$ century. They are proof of the tradition of this place, probably due to the availability and quality of the raw material. 
